\title{
PENERAPAN STRATEGI PEMBELAJARAN INTERAKTIF DALAM MENINGKATKAN HASIL BELAJAR IPA DI KELAS VI SD
}

Idris

SD Negeri 1 Riau Silip Kecamatan Riau Silip Kabupaten Bangka idrishincell@gmail.com

\begin{abstract}
Abstrak
Tujuan penelitian ini adalah untuk meningkatkan hasil pembelajaran dengan menggunakan strategi pembelajaran interaktif dalam proses pembelajaran IPA kelas VI SDN 1 Riau Silip. Hasil penelitian adalah sebagai berikut: (1) siswa terlibat tampak aktif mulai dari Siklus I sampai Siklus III; (2) meningkatnya hasil belajar siswa, yaitu penguasaan konsep siswa terhadap materi pembelajaran, yaitu mulai siklus I sampai Siklus III rata-rata nilai siswa meningkat sehingga mencapai angka rata-rata 87,83; dan (3) dari segi keaktifan siswa, skor rata-rata yang diperoleh pada Siklus III adalah sebesar 81,52 dan dari segi sikap kerja sama siswa diperoleh skor rata-rata sebesar 80,43 pada Siklus III. Berdasarkan hasil belajar, keaktifan, dan sikap kooperatif yang diperoleh siswa, dapat disimpulkan bahwa penerapan strategi pembelajaran interaktif dapat digunakan pada pembelajaran di sekolah, khususnya pembelajaran mengidentifikasi fungsi organ pernapasan manusia pada mata pelajaran IPA.
\end{abstract}

Kata kunci: Strategi Pembelajaran Interaktif, Hasil Belajar, Fungsi Organ Pernapasan Manusia

\section{Abstract}

The purpose of this study was to improve learning outcomes by using interactive learning strategis in the process of learning science class VI SDN 1 Riau Silip. The results of the study are as follows: (1) students involved appear active starting from Cycle I to Cycle III; (2) increasing student learning outcomes, namely mastery of students' concepts of learning material, namely starting from cycle I to Cycle III the average value of students increases so as to reach an average number of 87.83; and (3) in terms of student activeness, the average score obtained in Cycle III was 81.52 and in terms of student cooperation attitudes obtained an average score of 80.43 in Cycle III. Based on the results of learning, activeness, and cooperative attitudes obtained by students, it can be concluded that the application of interactive learning strategis can be used in learning in schools, especially learning to identify the functions of human respiratory organs in science subjects.

Keywords: Interactive Learning Strategi, Learning Outcomes, Function of Human Respiratory Organ 


\section{PENDAHULUAN}

Dalam pelaksanaan pembelajaran sehari-hari, masih banyak ditemukan siswa yang sulit memahami materi pelajaran, terutama untuk mata pelajaran IPA (Sains).Berdasarkan hasil yang dicapai siswa melalui tes formatif yang diberikan, menunjukkan kecilnya nilai IPA (Sains), siswa kelas VI SD Negeri 1 Riau Silip.Khususnya untuk materi mengidentifikasi fungsi organ pernapasan manusia yang diberikan, masih banyak siswa masih mengalami kendala dalam pelaksanaan pembelajaran sehingga perolehan tes formatif mereka tidak seperti yang diharapkan.

Berdasarkan analisis hasil pembelajaran, diperoleh data sebagai berikut.Nilai rata-rata yang diperoleh 25 siswa hanyalah sebesar $64 \%$ sedangkan rata-rata KKM adalah 70,00. Hanya 11 siswa atau $36 \%$ yang tuntas dalam pembelajaran dan $64 \%$ tidak tuntas dalam pembelajaran.

Kondisi ini memacupeneliti untuk meningkatkan pembelajaran dengan cara menerapkan pendekatan pembelajaran yang tepat. Atas dasar itulah, peneliti mencoba tentang pembelajaran tersebut. Hal tersebut sesuai dengan pendapat Trianto (2011: 9) yaitu suatu proses yang ditandai dengan adanya perubahan pada diri seseorang. Dalam penelitian ini, peneliti menggunakan pembelajaran interaktif.

Pengertian Strategi Pembelajaran Interaktif (Interactive Instruction). Pembelajaran interaktif ialah pembelajaran yang berfokus pada siswa, cara yang digunakan guru adalah dengan menggali pertanyaan-pertanyaan siswa (Abdul Majid, 2013: 84).

Dalam pelaksanaannya, pembelajaran interaktif lebih banyak pada diskusi dan sharing. Guru harus menyiapkan media yang interaktif dengan memberi kesempatan untuk menulis, selanjutnya mengajukan pertanyaan, dapat juga memberikan tanggapan dengan harapan proses belajar mengajar berjalan secara interaktif. 
Mengacu pada konsep pembelajaran interaktif tersebut, berikut adalah tahap-tahap pelaksanaan strategi pembelajaran interaktif mengacu pada pendapat Abdul Majid (2013: 88), yaitu :

1) tahap persiapan (preparation),guru dan siswa bersama-sama membahas topik yang akan dibahas dalam belajar;

2) pengetahuan awal (before view), guru menggali pemahaman siswa awal ttentang topik;

3) tahap kegiatan (exploratory), guru memancing keingintahuan siswa lalu siswa didorong agar bertanya;

4) tahap pertanyaan siswa (children questions), siswa diberi kesempatan bertanya pada kelompoknya setelah sebelumnya melaksanakan demonstrasi dan fenomene; 5) tahap penyelidikan (investigation), siswa berinteraksi dengan siswa lain, juga siswa dengan guru diberi kesempatan untuk mengelola konsep yang dipahami, sementara guru merancang kegiatan;

6) tahap pengetahuan akhir (after views), siwa menyampaikan hasil perolehan;

7) tahap refleksi (reflection), siswa bersama guru merview atas apa yang telah dipelajari.

Dengan menggunakan strategi pembelajaran ini, diharapkan minat belajar siswa pada mata pelajaran IPAakan meningkat sehingga hasil belajar mereka juga akan semakin baik. Sesuai dengan tujuan penelitian yaitu mengetahuipenerapan strategipembelajaran interaktif dalam meningkatkan hasil belajar IPA tentang materi mengidentifikasi fungsi organ pernapasan manusia pada siswa kelas VI SD Negeri 1 Riau Silip.

Penelitian ini diharapkan bermanfaat dalam rangka menerapkan dalam melaksanakanpembelajaran, salah satunya melalui penerapan strategi pembelajaran interaktif. Kemudian dijadikan teknik alternatif dalam proses pembelajaran, yang memacu para guru agar lebih kreatif dan inovatif dalam menyelenggarakan pembelajaran dengan cara menentukan media dan strategi pembelajaran baru. 


\section{METODE PENELITIAN}

Penelitian ini merupakan penelitian tindakan kelas (PTK) dengan 3 siklus dan setiap siklus terdiri dari empat tahap besar yaituperencanaan, pelaksanaan, pengamatan, dan refleksi. Selain menunjukkan empat tahap besar tersebut, PTK tidak sekali jalan kemudian selesai melainkan menunjukkan adanya siklus atau pengulangan. Pada langkah pelaksanaan peneliti menggunakan langkah-langkah strategi pembelajaran interaktif pada mata pelajaran IPA materi fungsi organ pernapasan manusia. Siswa yang dijadikan subjek penelitian adalah siswa kelas VI yang berjumlah 25 orang, yaitu 11 siswa laki-laki dan 14 siswa perempuan, di SD Negeri 1 Riau Silip, Kabupaten Bangka, Provinsi Kepulauan Bangka Belitung, beralamat di Jalan Raya Belinyu desa Riau, Kecamatan Riau Silip, Kabupaten Bangka.

\section{PEMBAHASAN}

\section{Deskripsi Penelitian}

Penelitian dilaksanakan dalam bentuk tindakan kelas ini dilaksanakan untuk mata pelajaran IPA kelas VI pada materi mengidentifikasi fungsi organ pernapasan manusia pada semester I tahun pembelajaran 2017/2018. Karakteristik dan kompetensi siswa termasuk beragam, yaitu kompetensi tinggi, sedang, dan rendah.

Adapun tahap-tahap pempelajaran adalah sebagai berikut: (1) tahap persiapan (preparation), guru dan siswa bersama-sama membahas topik yang akan dibahas dalam belajar; (2) pengetahuan awal (before view), guru menggali pemahaman siswa awal ttentang topik; (3) tahap kegiatan (exploratory), guru memancing keingintahuan siswa lalu siswa didorong agar bertanya; (4) tahap pertanyaan siswa (children questions), siswa diberi kesempatan bertanya pada kelompoknya setelah sebelumnya melaksanakan demonstrasi dan fenomena; (5) tahap penyelidikan (investigation), siswa berinteraksi dengan siswa lain, juga siswa dengan guru diberi kesempatan untuk mengelola konsep yang dipahami,

JIP: Jurnal Ilmiah PGMI, Volume 5 No. 1, Juni 2019 
sementara guru merancang kegiatan; (6) tahap pengetahuan akhir (after views), siwa menyampaikan hasil perolehan; (7) tahap refleksi (reflection), siswa bersama guru merview atas apa yang telah dipelajari.

Dalam perencanaan Siklus I, peneliti dibantu oleh teman sejawat terlebih dahulu merumuskan masalah yang terjadi sebelum dilakukan perbaikan, yaitu siswa belum mampu menguasai materi pelajaran IPA pada materi mengidentifikasi fungsi organ pernapasan manusia. Adapun kegiatan yang dilakukan adalah sebagai berikut: menyiapkan rencana perbaikan pembelajaran Siklus I, menyiapkan lembar observasi, lembar evaluasi, lembaran LKS.

Tindakan di Siklus I adalah meningkatkan kemampuan siswa dalam menguasai materi tentang organ pernapasan manusia.Pada awal pertemuan, guru memberikan apersepsi.Setelah siswa siap menerima pelajaran, pembelajaran dimulai oleh guru.

Siswa dibagi dalam beberapa kelompok yang dalam kelompok tersebut terdapat siswa dari kelompok tinggi dan siswa yang berasal dari kelompok sedang dan rendah. Selanjutnya, siswa secara berkelompok mengerjakan tugas pada lembar kerja. Guru mengamati keaktifan siswa. Setelah selesai pembahasan, siswa secara individu menyelesaikan tes penguasaan materi yang telah disiapkan oleh guru. Pengamatan dilakukan dengan cara melakukan pengamatan terhadap pelaksanaan pembelajaran dengan berpedoman pada lembar observasi yang telah disiapkan. Pengamatan dilakukan terhadap kinerja guru saat melakukan pembelajaran dan keaktifan siswa selama pembelajaran berlangsung dengan memberikan checklist sesuai dengan kondisi pembelajaran yang sesungguhnya.

Refleksi dilakukan dengan cara-cara sebagai berikut: menganalisis pelaksanaan pembelajaran yang menerapkan strategi pembelajaran interaktif, yaitu menganalisis kelemahan dan keberhasilan guru saat menerapkan pembelajaran tersebut. Melakukan refleksi terhadap proses pembelajaran yang menerapkan strategi pembelajaran interaktif dan mempertimbangkan langkah pembelajaran selanjutnya. Melakukan refleksi terhadap keaktifan siswa dalam pembelajaran IPA. Melakukan refleksi terhadap hasil belajar siswa. Berdasarkan 88

JP: Jurnal Ilmiah PGMI, Volume 5 No. 1, Juni 2019 Available Online at http:/jurnal.radenfatah.ac.id/index.php/jip/ 
hasil refleksi, kekurangan yang belum bisa diatasi pada Siklus I akan diperbaiki pada Siklus II. Perencanaan pembelajaran Siklus II didasarkan pada kekurangan pembelajaran Siklus I. Dalam perencanaan Siklus II, peneliti dibantu oleh teman sejawat terlebih dahulu merumuskan masalah yang terjadi sebelum dilakukan perbaikan, yaitu siswa belum mampu menguasai materi pembelajaran IPA. Adapun kegiatan yang dilakukan adalah sebagai berikut. Menyiapkan rencana perbaikan pembelajaran Siklus II. Menyiapkan lembar observasi, lembar evaluasi, lembar kerja siswa.

Tindakan yang dilakukan pada Siklus II adalah meningkatkan kemampuan dalam menguasai materi mengidentifikasi fungsi organ pernapasan manusia. Pada awal pertemuan, guru menjelaskan tujuan pembelajaran, mengingatkan siswa tentang materi pelajaran yang telah dipelajari pada pertemuan sebelumnya, dan memotivasi siswa untuk menerima materi pelajaran.

Sama dengan Siklus I, siswa dibagi dalam beberapa kelompok yang dalam kelompok tersebut terdapat siswa dari kelompok tinggi dan siswa yang berasal dari kelompok sedang dan rendah. Selanjutnya, siswa secara berkelompok mengerjakan tugas pada lembar kerja. Guru mengamati keaktifan siswa. Setelah selesai pembahasan, siswa secara individu menyelesaikan tes penguasaan materi yang telah disiapkan oleh guru.

Pengamatan dilakukan dengan cara melakukan pengamatan terhadap pelaksanaan pembelajaran. Pengamatan dilakukan terhadap kinerja guru saat melakukan pembelajaran dan keaktifan siswa dengan memberikan checklist.

Melakukan refleksi terhadap proses pembelajaran selanjutnya.Melakukan refleksi terhadap keaktifan siswa dalam pembelajaran IPA.Melakukan refleksi terhadap hasil belajar siswa.Berdasarkan hasil refleksi, kekurangan yang belum bisa diatasi pada siklus berikutnya.

Keberhasilan terlihat dari aspek proses yakni keaktifan dalam mengikuti proses pembelajaran. Selain keaktifan tersebut, keantusiasan ditandai dengan terjalinnya sikap kooperatif siswa selama proses pembelajaran. 
Selain keaktifan tersebut, keantusiasan ditandai dengan terjalinnya sikap kooperatif siswa selama proses pembelajaran. Data keaktifan dan sikap kooperatif ini dijaring dengan lembar pengamatan yang dilakukan pada bagian rencana dan prosedur penelitian. Adapun kategorisasi tingkat keaktifan dan sikap kooperatif mengacu kepada Departemen Pendidikan dan Kebudayaan (1996), dengan rincian tabel.

Dari segi hasil (nilai tes), secara individu, keberhasilan hasil belajar siswa ditentukan oleh nilai KKM sebesar 70,00. Siswa yang mendapatkan nilai tes < 70,00 dikategorikan tidak tuntas. Sebaliknya, siswa yang mendapatkan nilai tes $\geq$ 70,00 dikategorikan tuntas.

\section{Hasil Pra Siklus}

Sebelum penelitian dilaksanakan, pembelajaran IPA dilaksanakan dengan pembelajaran tradisional. Efeknya adalah nilai siswa banyak yang di bawah KKM. Ini jelas berdampak pada pembelajaran berikutnya.

Dari hasil tes evaluasi siswa didapat 3 siswa yang dapat mencapai KKM dan selebihnya siswa mendapat nilai di bawah KKM. Hal ini dapat dikatakan kemampuan siswa dalam belajar kurang.

\section{Hasil Siklus I}

Kemampuan siswa dalam penguasaan konsep pada Siklus I mendapat nilai rata-rata 70,35 dan termasuk kategori cukup. Nilai terendah adalah 40 dan nilai tertinggi adalah 100. Sebanyak 14 orang siswa atau 60,87\% tuntas dalam pembelajaran. Berdasarkan hasil tes keaktifan siswa dalam mengikuti pelajaran yang diukur melalui mendengarkan penjelasan guru mendapatkan skor rata-rata 65,22 (kategori sedang); menulis/mencatat materi penting mendapatkan skor ratarata 69,57 (kategori sedang); mengerjakan LKS mendapatkan skor rata-rata 73,91 (kategori tinggi); dan mengajukan pertanyaan pada teman/guru mendapatkan skor rata-rata 43,48 (kategori rendah). 
Dapat disimpulkan, secara keseluruhan, tingkat keaktifan siswa termasuk kategori sedang dengan skor rata-rata 63,04. Dan dari hasil sikap kooperatif siswa dalam mengikuti pelajaran yang diukur melalui menghargai pendapat orang lain mendapatkan skor rata-rata 60,87 (kategori sedang); memberikan kesempatan kepada orang lain untuk berbicara mendapatkan skor rata-rata 60,87 (kategori sedang); kerja sama dalam kelompok mendapatkan skor rata-rata 73,91 (kategori tinggi); dan kemampuan dalam mengeluarkan pendapat mendapatkan skor ratarata 43,48 (kategori rendah). Dengan demikian, secara keseluruhan, tingkat sikap kooperatif siswa mendapatkan skor rata-rata 59,78 (kategori rendah).

\section{Hasil SiklusII}

Kemampuan siswa dalam penguasaan konsep pada Siklus II mendapat nilai rata-rata 81,13 dan termasuk kategori baik. Nilai terendah adalah 52 dan nilai tertinggi adalah 100. Sebanyak 16 orang siswa atau $69,57 \%$ tuntas dalam pembelajaran. Keaktifan siswa dalam mengikuti pelajaran yang diukur melalui mendengarkan penjelasan guru mendapatkan skor rata-rata 73,91 (kategori tinggi); menulis/mencatat materi penting mendapatkan skor rata-rata 78,26 (kategori tinggi); mengerjakan LKS mendapatkan skor rata-rata 82,61 (kategori tinggi); dan mengajukan pertanyaan pada teman/guru mendapatkan skor rata-rata 52,17 (kategori rendah).

Dengan demikian, secara keseluruhan, tingkat keaktifan siswa termasuk kategori tinggi dengan skor rata-rata 71,74.bahwa sikap kooperatif siswa dalam mengikuti pelajaran yang diukur melalui menghargai pendapat orang lain mendapatkan skor rata-rata 69,57 (kategori sedang); memberikan kesempatan kepada orang lain untuk berbicara mendapatkan skor rata-rata 69,57 (kategori sedang); kerja sama dalam kelompok mendapatkan skor rata-rata 82,61 (kategori tinggi); dan kemampuan dalam mengeluarkan pendapat mendapatkan skor ratarata 52,17 (kategori rendah). Dengan demikian, secara keseluruhan, tingkat sikap kooperatif siswa mendapatkan skor rata-rata 68,48 (kategori sedang). 


\section{Hasil SiklusIII}

Kemampuan siswa dalam penguasaan konsep pada Siklus III mendapat nilai rata-rata 87,83 dan termasuk kategori sangat baik. Nilai terendah adalah 64 dan nilai tertinggi adalah 100. Sebanyak 21 orang siswa atau 91,30\% tuntas dalam pembelajaran. Keaktifan siswa dalam mengikuti pelajaran yang diukur melalui mendengarkan penjelasan guru mendapatkan skor rata-rata 86,96 (kategori sangat tinggi); menulis/mencatat materi penting mendapatkan skor rata-rata 86,96 (kategori sangat tinggi); mengerjakan LKS mendapatkan skor rata-rata 91,30 (kategori sangat tinggi); dan mengajukan pertanyaan pada teman/guru mendapatkan skor rata-rata 60,87 (kategori sedang). Dengan demikian, secara keseluruhan, tingkat keaktifan siswa termasuk kategori tinggi dengan skor ratarata 81,52 .

Sikap kooperatif siswa dalam mengikuti pelajaran yang diukur melalui menghargai pendapat orang lain mendapatkan skor rata-rata 82,61 (kategori tinggi); memberikan kesempatan kepada orang lain untuk berbicara mendapatkan skor rata-rata 86,96 (kategori sangat tinggi); kerja sama dalam kelompok mendapatkan skor rata-rata 91,30 (kategori sangat tinggi); dan kemampuan dalam mengeluarkan pendapat mendapatkan skor rata-rata 60,87 (kategori sedang). Dengan demikian, secara keseluruhan, tingkat sikap kooperatif siswa mendapatkan skor rata-rata 80,43 (kategori tinggi).

Berdasarkan hasil penelitian, dapat dilihat perkembangan tiap siklus sebagai berikut:

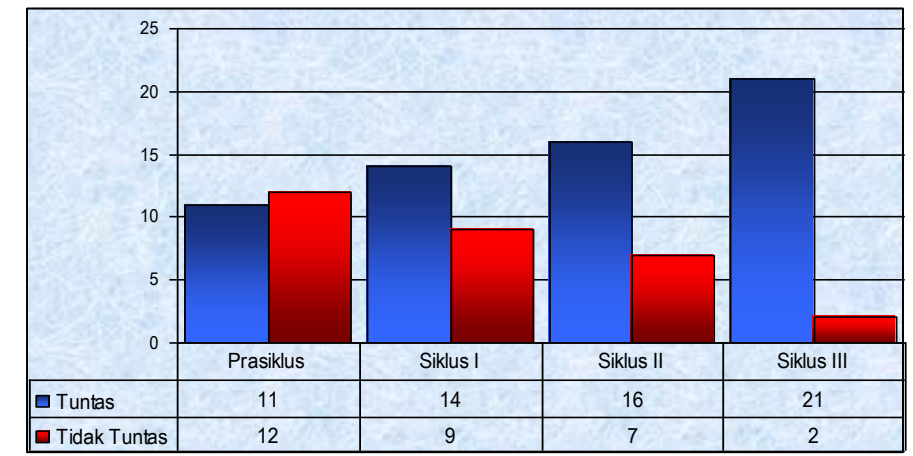

Gambar 1. Data Ketuntasan Belajar Siswa pada Tiap-tiap Siklus 


\section{SIMPULAN}

Berdasarkan hasil perbaikan pembelajaran yang telah dilaksanakan, dapat ditarik kesimpulan-kesimpulan bahwa, penerapan pembelajaran strategi pembelajaran interaktifpada siswa kelas VI SD Negeri 1 Riau Silip untuk materi mengidentifikasi fungsi organ pernapasan manusia pada mata pelajaran IPA telah memberikan hasil yang maksimal, baik dari aspek penguasaan konsep siswa yang mencapai skor rata-rata sebesar 87,83; keaktifan siswa yang mencapai skor ratarata sebesar 81,52; maupun sikap kooperatif siswa yang mencapai skor rata-rata sebesar 80,43 . Penerapan strategi pembelajaran interaktif membantu siswa dalam memahami materi mengidentifikasi fungsi organ pernapasan manusia. Penerapan strategi pembelajaran interaktif dalam pembelajaran dapat meningkatkan kemampuan akademik siswa, partisipasi siswa dalam pembelajaran, dan keaktifan mereka dalam memahami konsep IPA. Berdasarkan kesimpulan di atas, guru mata pelajaran IPA hendaknya menerapkan strategi pembelajaran interaktif, khususnya dalam materi organ karena berdasarkan hasil penelitian penulis, strategi tersebut meningkatkan hasil belajar siswa pada aspek penguasaan konsep oleh siswa, keaktifan siswa, maupun sikap kooperatif siswa. Adapun pembelajaran kooperatif, membuat pembelajaran menjadi aktif, kreatif, partisipatif, dan menyenangkan.Guru disarankanmenggunakan ini membantu siswa memahami tujuan pembelajaran.

\section{DAFTAR PUSTAKA}

Departemen Pendidikan dan Kebudayaan. (1996). Petunjuk Teknis Penilaian Pendidikan. Jakarta. Dirjen Dikdasmen.

Depdiknas. (2006). Pedoman Khusus Pengembangan Sistem Penilaian Mata Pelajaran Sains. Jakarta: Direktorat Pendidikan Dasar.

Djohar. (2000). Struktur IPA. Yogyakarta: Jurusan Pendidikan Biologi FMIPA UNY.

Ibrahim, M., dan Nur., M.. (2000). Pengajaran Berdasarkan Masalah. Surabaya: University Press.

Kardi, S. dan Nur, M. (2000). Pengajaran Langsung. Surabaya: University Press.

Majid Abdul.(2013), Strategi Pembelajaran. Bandung, PT. REMAJA ROSDAKARYA. 
Nur, M. (2002). Psikologi Pendidikan: Fondasi untuk Pengajaran. Surabaya: University Press.

Sanjaya, Wina. (2008). Perencanaan dan Desain Sistem Pembelajaran. Jakarta: Kencana.

Suciati dkk.. (2002). Belajar dan Pembelajaran. Jakarta: Pusat Penerbitan Universitas Terbuka.

Trianto. (2011). Strategi Pembelajaran Terpadu Konsep, Strategi dan Implementasi dalam Kurikulum Tingkat Satuan Pendidikan (KTSP), Jakarta: Bumi Aksara 